\title{
Psychological morbidity in Leber's hereditary optic neuropathy depends on phenotypic, social, economic, and genetic factors
}

This article was published in the following Dove Press journal:

Clinical Ophthalmology

22 May 2017

Number of times this article has been viewed

\section{Josef Finsterer'}

Sinda Zarrouk-Mahjoub ${ }^{2}$

'Krankenanstalt Rudolfstiftung, Vienna, Austria; ${ }^{2}$ University of Tunis El Manar, Genomics Platform, Pasteur Institute of Tunis, Tunis, Tunisia
Correspondence: Josef Finsterer Postfach 20, I 180 Vienna, Austria Tel +43 I 7I I65 92085

Fax +43 | 478। 7। |

Email fipaps@yahoo.de

\section{Dear editor}

We have read with interest the article by Garcia et $\mathrm{al}^{1}$ about the effect of visual impairment on psychological well-being with regard to mood, interpersonal interactions, and career-related goals. ${ }^{1}$ Among the 103 Leber's hereditary optic neuropathy (LHON) patients, half became depressed with negative impacts on interpersonal relations and career goals. At diagnosis, older age corresponded to higher depression prevalence than young age. We have the following comments and concerns.

The main disadvantage of the study is that the included patients were not categorized according to the underlying genetic defect. The genetic cause of LHON is quite heterogeneous. ${ }^{2}$ The three primary LHON mutations m.11778G $>$ A, m.3460G $>$ A, and m.14484T $>$ C, located in the ND4, ND1, and ND6 mtDNA genes of the mitochondrial DNA (mtDNA), respectively, account for $90 \%$ of the LHON cases. ${ }^{2}$ In addition, a number of other mtDNA mutations, such as m.3434T $>$ C, m.3483G $>$ A, m.3635G $>$ A, m.3866T $>$ C, m.9011T $>$ C, m.11253T $>$ C, m.11696G $>$ A, or m.13042G $>$ A, may be implicated in the pathogenesis of LHON. ${ }^{3}$ Did the results vary between the three primary LHON mutations? Differentiation between the three mutations is of particular importance since spontaneous recovery of visual compromise has been reported in a small number of cases with LHON. ${ }^{4}$ Remission is most pronounced in patients carrying the m.14484T $>$ C mutation. ${ }^{2}$ How many among the 103 included patients carried this particular mutation and how many showed improvement in visual dysfunction during the disease course? The type of mutation may also determine the risk of mutation carriers to develop symptoms. ${ }^{2}$

LHON is frequently not only a monoorgan disorder affecting the optic nerve and the retinal ganglion cells (pure LHON) but also usually a multisystem disease, additionally involving the brain (epilepsy, leucoencephalopathy, migraine, ataxia, chorea, dementia, and posterior reversible encephalopathy syndrome [PRES]), the ears (hypoacusis), endocrine organs (diabetes, thyroid dysfunction, and pituitary adenoma), the heart (cardiomyopathy, noncompaction, arrhythmias, heart failure, and sudden cardiac death), the kidneys, the bone marrow (anemia), the arteries (aortic stiffness), or the peripheral nerves (polyneuropathy) (LHON plus). ${ }^{3}$ How many patients had pure LHON and how many LHON plus? Did the results differ between those with pure LHON and those with LHON plus?

Idebenone has been shown to partially improve visual compromise and has been approved as a supporting remedy for LHON in some countries. ${ }^{5}$ How many of the 
included patients were under a therapy with idebenone when filling out the questionnaire? Were those under idebenone less frequently depressed than those without this therapy?

Mean interval between conversion and time of survey was $5 \pm 1.3$ years. ${ }^{1}$ Did the results differ between those asked shortly after conversion and those asked long after visual loss?

Overall, this interesting study may be more meaningful if the cohort would be divided according to the underlying genetic cause, the length of the interval between conversion and questionnaire, the clinical presentation (pure LHON vs LHON plus), and the treatment applied.

\section{Disclosure}

The authors report no conflicts of interest in this communication.

\section{References}

1. Garcia GA, Khoshnevis M, Gale J, et al. Profound vision loss impairs psychological well-being in young and middle-aged individuals. Clin Ophthalmol. 2017;11:417-427.

2. Yu-Wai-Man P, Chinnery PF [database on the Internet]. Leber hereditary optic neuropathy; 2000 [updated June 23, 2016]. In: Pagon RA, Adam MP, Ardinger $\mathrm{HH}$, et al, editors. GeneReviews ${ }^{\circledR}$ [Internet]. Seattle, WA: University of Washington, Seattle; 1993-2017. Available from: http:// www.ncbi.nlm.nih.gov/books/NBK1174/. Accessed April 28, 2017.

3. Finsterer J, Zarrouk-Mahjoub S. Leber's hereditary optic neuropathy is multiorgan not mono-organ. Clin Ophthalmol. 2016;10:2187-2190.

4. Leo-Kottler B, Luberichs J, Besch D, Christ-Adler M, Fauser S. Leber's hereditary optic neuropathy: clinical and molecular genetic results in a patient with a point mutation at $\mathrm{np} \mathrm{T} 11253 \mathrm{C}$ (isoleucine to threonine) in the ND4 gene and spontaneous recovery. Graefes Arch Clin Exp Ophthalmol. 2002;240(9):758-764.

5. Klopstock T, Yu-Wai-Man P, Dimitriadis K, et al. A randomized placebocontrolled trial of idebenone in Leber's hereditary optic neuropathy. Brain. 2011;134(pt 9):2677-2686. 


\section{Authors' reply \\ Giancarlo A Garcia ${ }^{1,2}$ \\ Matin Khoshnevis ${ }^{1,3}$ \\ Jesse Gale ${ }^{1,4}$ \\ Starleen E Frousiakis ${ }^{1,5}$ \\ Tiffany J Hwang ${ }^{1,6}$ \\ Lissa Poincenot ${ }^{1}$ \\ Rustum Karanjia ${ }^{1,7-9}$ \\ David Baron ${ }^{6}$ \\ Alfredo A Sadun ${ }^{1,7}$}

'Doheny Eye Institute, Los Angeles, ${ }^{2}$ University of California, Irvine School of Medicine, Irvine, CA, ${ }^{3}$ Department of Ophthalmology, Temple University, Philadelphia, PA, USA; ${ }^{4}$ Wellington School of Medicine and Health Sciences, University of Otago, Wellington, New Zealand; ${ }^{5}$ Department of Ophthalmology, New York Medical College, Valhalla, NY, 'Department of Psychiatry \& The Behavioral Sciences, Keck School of Medicine, University of Southern California, Los Angeles, 'Department of Ophthalmology, Doheny Eye Centers, David Geffen School of Medicine at UCLA, CA, USA; ${ }^{8}$ Department of Ophthalmology, University of Ottawa, ${ }^{9}$ Ottawa Hospital Health Research Institute, Ottawa, ON, Canada

Correspondence: Giancarlo A Garcia

Doheny Eye Institute, 800 South Fairmount Avenue, Suite 215,

Pasadena, CA 9II05, USA

$\mathrm{Tel}+\mathrm{I} 626817470 \mathrm{I}$

Fax +l 6268174702

Email garcia.giancar@gmail.com

\section{Dear editor}

We appreciate Dr Finsterer and Dr Zarrouk-Mahjoub's interest in our article ${ }^{1}$ and regret that many of their questions cannot be addressed by the nature of our study. Their most salient inquiries were as follows: did mutation affects visual prognosis, risk of vision loss, or psychological morbidity? Were systemic health associations associated with psychological morbidity? Did idebenone therapy affects psychological morbidity? Did the recency of vision loss affects psychological morbidity? Our study was not designed to collect data on these questions.

Among our respondents, the self-reported mutations were $55 \% \mathrm{~m} .11778 \mathrm{G}>\mathrm{A}, 11 \% \mathrm{~m} .14484 \mathrm{~T}>\mathrm{C}, 11 \% \mathrm{~m} .3460 \mathrm{G}>\mathrm{A}$, $20 \%$ unknown, and $3 \%$ other. This demonstrates that nonprimary mutations are very uncommon in Leber's hereditary optic neuropathy (LHON). Mutation clearly affects visual prognosis. ${ }^{2}$ Mutation type also affects the risk of conversion, but this is harder to measure. ${ }^{3}$ In our anonymous questionnaire study, participants self-reported their visual acuity and did not describe the course of vision loss, so we could not analyze whether mutation affected visual prognosis in this cohort. We did not find significant differences in depression symptoms between mutations. There are several reasons why mutation, vision, and depression were not clearly interrelated in our participants - most notably selection bias, small subgroups, and the pitfalls of post hoc analysis.

We disagree that systemic associations are common in LHON. In support of their contention, Dr Finsterer and Dr Zarrouk-Mahjoub cite their own literature review, which considers $\sim 22$ case reports of others. Without a "denominator," and in the face of such ascertainment bias, it is impossible to demonstrate whether an associated finding has a raised prevalence among the rare patients with LHON. Indeed Orphanet, maintained by a consortium of institutions lead by Inerm, estimates the prevalence of LHON plus at less than one in a million, considerably lower than that of LHON, which is estimated at 1:50,000.,5 Our respondents were not asked specifically about systemic illnesses or idebenone therapy, and these did not appear to play a role in qualitative analyses of their psychological morbidity. ${ }^{6}$

The recency of vision loss did appear to be associated with psychological morbidity in a parallel study. ${ }^{6}$ Predictably, those who lost vision many years earlier were more likely to have made a psychological recovery. Even so, it was noteworthy that many participants had severe psychological symptoms years after vision loss.

We note that Dr Finsterer and Dr Zarrouk-Mahjoub have published $\sim 60$ letters to editors in the last 6 months. We believe that readers should be aware that high-volume letter writing has the potential to be superficial and off point, failing to reflect on the nature of the studies in question or on previously published findings.

\section{Disclosure}

The authors report no conflicts of interest in this communication.

\section{References}

1. Garcia GA, Khoshnevis M, Gale J, et al. Profound vision loss impairs psychological well-being in young and middle-aged individuals. Clin Ophthalmol. 2017;11:417-427.

2. Howell N, Kubacka I, Halvorson S, Howell B, McCullough DA, Mackey D. Phylogenetic analysis of the mitochondrial genomes from Leber hereditary optic neuropathy pedigrees. Genetics. 1995;140(1):285-302.

3. Newman NJ. Leber's hereditary optic neuropathy. New genetic considerations. Arch Neurol. 1993;50(5):540-548.

4. Oprhanet [webpage on the Internet]. Leber Hereditary Optic Neuropathy. Available from: http://www.orpha.net/consor/cgi-bin/OC_Exp.php? Expert=104. Accessed April 11, 2016.

5. Yu-Wai-Man P, Chinnery PF [database on the Internet]. Leber hereditary optic neuropathy; 2000 [updated June 23, 2016]. In: Pagon RA, Adam MP, Ardinger $\mathrm{HH}$, et al, editors. GeneReviews ${ }^{\circledR}$ [Internet]. Seattle, WA: University of Washington, Seattle; 1993-2017. Available from: http:// www.ncbi.nlm.nih.gov/books/NBK1174/. Accessed April 28, 2017.

6. Gale J, Khoshnevis M, Frousiakis SE, et al. An international study of emotional response to bilateral vision loss using a novel graphical online assessment tool. Psychosomatics. 2017;58(1):38-45. 
Dove Medical Press encourages responsible, free and frank academic debate. The content of the Clinical Ophthalmology 'letters to the editor' section does not necessarily represent the views of Dove Medical Press, its officers, agents, employees, related entities or the Clinical Ophthalmology editors. While all reasonable steps have been taken to confirm the content of each letter Dove Medical Press accepts no liability in respect of the content of any letter, nor is it responsible for the content and accuracy of any letter to the editor.

Clinical Ophthalmology

\section{Publish your work in this journal}

Clinical Ophthalmology is an international, peer-reviewed journal covering all subspecialties within ophthalmology. Key topics include: Optometry; Visual science; Pharmacology and drug therapy in eye diseases; Basic Sciences; Primary and Secondary eye care; Patient Safety and Quality of Care Improvements. This journal is indexed on

\section{Dovepress}

PubMed Central and CAS, and is the official journal of The Society of Clinical Ophthalmology (SCO). The manuscript management system is completely online and includes a very quick and fair peer-review system, which is all easy to use. Visit http://www.dovepress.com/ testimonials.php to read real quotes from published authors. 